\title{
KOMBINIRANI MODALITETI LIJEČENJA NEMIKROCELULARNOG KARCINOMA PLUĆA - NAŠA ISKUSTVA
}

\author{
COMBINED JUVENILES OF MEDICAL TRAETMENTS OF NON-MICROCELULARS LUNG \\ CANCER - OUR EXPERIENCES
}

\author{
Ademir Hadžismailović , Kemal Grbić, Pilav Alen , Alma Alihodžić-Pašalić
}

\begin{abstract}
Sažetak: Uvod: U najvećem broju slučajeva karcinom bronha je oboljenje koje se otkriva u uznapredovaloj fazi bolesti, kada je radikalni hirurški tretman, kao nabitniji vid liječenja ograničen. Cilj neoadjuvantnog hemoterapijskog tretmana je dovesti bolest u stanje, kada je ono moguće. Cilj rada: Prikazati naša iskustva u uspješnosti primjene preoperativnog onkološkog modaliteta liječenja $i$ efikasnost prevođenja bolesti $u$,niži stadij“. Pacijenti i metode: U analizi je posmatrano 67 pacijenata raznih starosnih $i$ spolnih skupina, kod kojih je inicijalno nakon potvrde dijagnoze, a zbog lokalizacije i proširenosti oboljenja, bilo nemoguće sprovesti hirurško liječenje. Navedeni su nakon interdisciplinarnog pristupa, tretirani neoadjuvantnim hemoterapijskim protokolom, te nakon istog radiografsko-bronhološki reevaluirani i operirani. Rezultati: Ne postoji statistički značajna razlika u prosječnim vrijednostima starosti pacijenata u odnosu na njihov spol. (p=0,052) Statistički postoji značajna razlika u učestalosti pojavljivanja između dvije najčešće vrste plućnog karcinoma kod ukupnog broja pacijenata. $\left(\chi^{2}\right.$ test $\left.=10,056 ; p=0,002\right)$ Razlika u veličini regresije prema vrsti tumora nije statistički značajna. $p=0,091$. Zaključak: Značajan efekat multimodalnog tretmana nemikrocelularnog karcinoma pluća.
\end{abstract}

Ključne riječi: Karcinom pluća, neoadjuvantna onkološka terapija, hirurški tretman.

\section{UVOD}

Dug evolutivni tok, prikrivena klinička slika, te kasna detekcija karcinoma pluća, najčešće u fazi kada je resektabilnost ograničena i nemoguća, a koja predstavlja nejpotentniji način liječenja, predstavlja ovu bolest kao veliki zdravstveni problem današnjice.(1) Prilikom operacije, radikalna i potpuno kurativna resekcija je učinjena, kada se potpuno ukloni primarni tumor uz limfadenektomiju regionalnih limfnih čvorova, makroskopski vidljive tumorske infiltracije, te kada se potvrdi da su resekcioni rubovi bez mikroskopskog prisustva maligniteta. $(2,3)$

Kod patohistološki verificiranog karcinoma pluća, a kojeg zbog veličine/odnosa prema intratorakalnim strukturama ili maligne infiltracije N2 nivoa limfnih nodusa (stadij III bolesti), nije moguće tretirati hirurški, u multidisciplinarnom pristupu tretiramo preoperativno cisplatinski baznom dvojnom hemoterapijom sa 2-6 ciklusa, uz radiološko-bronhoskopsku reevluaciju stanja i ponovnu procjenu resektabilnosti.

Značajan doprinos isvjesnom terapijskom napretku pruža i sve češća primjena PET-CT-a, kojom se otkrivaju suspektne plućne i medijastinalne lezije u ranoj fazi bolesti, VATS biopsija limfnih čvorova, medijastinoskopija i EUS sa aspiracionom iglenom biopsijom. Od terapije se očekuje da efikasno redukuje neresektabilnu leziju do dimenzija, kada je moguća resekcija kojom se ostvaruje radikalnost, uklanja lokalna bolest i na početku liječenja zaustavlja sistemska diseminacija.(4)

\section{CILJ RADA}

Rad prkazuje naša iskustva $u$ efikasnosti primjene neoadjuvantne terapije kod inicijalno inoperabilnog i granično operabilnog nemikrocelularnog plućnog karcinoma, prikaz regresiju promjene $u$ veličini, te efikasnost onkološkog tretmana kao preduslov resekcije inicijalno inoperabilnog/neresektabilnog plućnog 
karcinoma, te brojčani prikaz učestalost ranih postoperativnih komplikacija u odnosu na vrstu učinjenog hiruškog zahvata.

\section{PACIJENTI I METODE}

U radu je analizirano 67 pacijenta raznih starosnih grupa oba spola, koji su operirani na Klinici za torakalnu hirurgiju KCU u Sarajevu, nakon sprovedenih 2 do 6 ciklusa neoadjuvantne onkološke terapije zbog inperabilnog ili granično operabilnog nemikrocelularnog plućnog karcinoma prilikom, a prema odluci interdisciplinarnog konzilija za tumore. Primjenjivani su različiti terapijski modaliteti sa cisplatinom kao baznom terapijom.

Bronhopulmološka dijagnostička obrada pacijenta je rađena na Klinici za plućne bolesti Podhratosvi UKC-a u Sarajevu, a minimalno je sadržavala CT grudnog koša uz intravensku aplikaciju kontrasnog sredstva, bronhoskopski i spirometrijski nalaz, ultrazvučni pregled trbuha, kako prije, tako i nakon onkološke tarapije. Patohistološka dijagnoza je postavljena prema standardnim histološkim tipovima tumora, na Institutu za kliničku patologiju UKC-a u Sarajevu, a uzorci tumora su uzimani endoluminalnom biopsijom tokom bronhoskopije, radiografski vođenom transtorakalnom iglenom biopsijom ili torakoskopskim zahvatom.

U našoj analizi inicijalna veličina tumora je uzeta prema radiografskom nalazu prije terapije (CT-u), odnosno postoperativnom patohistološkom nalazu. Resekcioni zahvati su rađeni standardnim posteroletarlnim torakotomijskim pristupom, uz separisanu anesteziju. Vaskularni elementi su resecirani vaskularnim samošivačima ili duplim ligiranjem, dok su bronhijalne strukture uvijek resecirane lineranim staplerima, uz prezervaciju bataljka bronha transpozicioniranom peteljkom interkostalnog mišića ili pleure. U tabeli su evidentirane samo one komplikacije koje su se javile prije otpusta pacijenta.

\section{REZULTATI:}

Tabela 1. Starosna i spolna struktura analiziranih pacijenata

\begin{tabular}{|lc|c|c|c|}
\hline Opisna statistika & Muškarci & Žene & Ukupno \\
\hline Frekvenca (f/N) & 52 & 15 & 67 \\
\hline Aritmetička sredina & 61,4 & 59,8 & 60,6 \\
\hline
\end{tabular}

\begin{tabular}{|l|c|c|c|}
\hline (AS) & & & \\
\hline Standardna greška AS & 0,3 & 0,4 & 0,3 \\
\hline $\begin{array}{l}\text { Standardna devijacija } \\
\text { (SD) }\end{array}$ & 0,8 & 2,2 & 0,9 \\
\hline Minimum (godine) & 47 & 39 & 39 \\
\hline Maximum (godine) & 77 & 69 & 77 \\
\hline
\end{tabular}

$\mathrm{Ne}$ postoji statistički značajna razlika u prosječnim vrijednostima starosti pacijenata $u$ odnosu na njihov spol. $\mathrm{p}=0,052$

Učestalost planocelularnog karcinoma u posmatranoj grupi je bila 74,6\% (50/67), adenokarcinoma $\quad 22,4 \% \quad(15 / 67), \quad$ te makrocelularnog karcinoma $3,0 \%(2 / 67) . \quad \chi^{2}$ test $=$ $27 ; \mathrm{p}=0$

Frekvenca tipa karcinoma u odnosu prema spolu, je prikazana na grfikonu 1 .

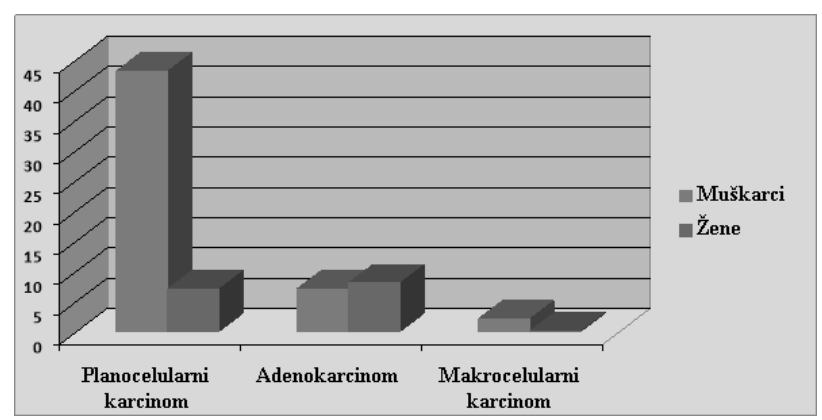

Grafikon 1. Zastupljenost tipa karcinoma u odnosu na spol

Statistički postoji značajna razlika u učestalosti pojavljivanja između dvije najčešće vrste plućnog karcinoma kod ukupnog broja pacijenata. $\chi^{2}$ test $=$ 10,056; $\mathrm{p}=0,002$ Fisher-ovim egzaktnim testom utvrđena je statistički značajna razlika u učestalosti pojedinih tipova karcinoma pluća prema spolu. $\mathrm{p}=0$

Slikoviti prikaz regresije veličine tumora nakon sprovedenog neoadjuvantnog hemoterapijskog tretmana u zavisnosti od tipa. je prikazan na grafikonu 2 .

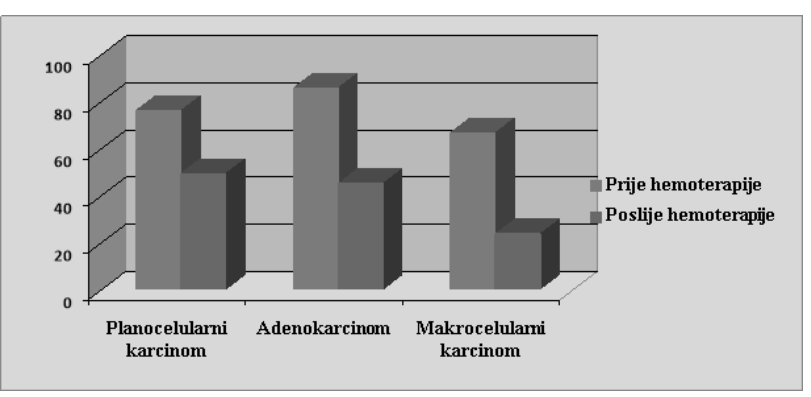


Grafikon 2. Prikaz regresije tumora na sprovedeni neoadjuvantni tretman

Analizirajući veličinu regresije $u$ odnosu na tip karcinoma, izračunata vrijednost medijane i interkvartilnog raspona smanjenja veličine kod planocelularnog karcinoma je $26,5 \mathrm{~mm}(17,0-$ $38,0)$, adenokarcinoma $38,0 \mathrm{~mm}(24,0.42,0)$ i makrocelularnog karcinoma 20,0 mm (18,0-22,0). Razlika u veličini regresije prema vrsti tumora nije statistički značajna. $p=0,091$

Vrsta urađenog operativnog zahvata nakon sprovedenog neoadjuvantnog hemoterapijskog tretmana i radiološko-bronhoskopske reevaluacije, je prikazana na grafikonu 3 .

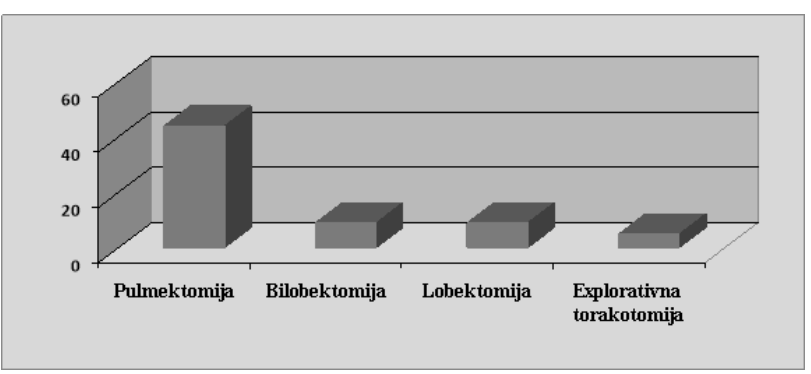

Grafikon 3. Vrsta urađenog operativnog zahvata

Od urađenih operativnih zahvata 65,7\% (44/67) su pulmektomije, bilobektomije i lobektomije su sa istim procentualnim učešćem $13,4 \%(9 / 67)$ i $7,5 \%$ (5/67) eksplorativne torakotomije.

Od ukupnog broja pacijenata $32(47,8 \%)$ su nakon urednog postoperativnog toka $\mathrm{i}$ bez značajnih komplikacija otpušteni kući, dok su se kod $35(52,2 \%)$ javile komplikacije, a kako je prikazano u tabeli 2 .

Tabela 2. Numerički prikaz učestalosti postoperativnih komplikacija

\begin{tabular}{|l|c|c|c|}
\hline Komplikacija & $\begin{array}{c}\text { Pulmekt } \\
\text { omija }\end{array}$ & $\begin{array}{c}\text { Lobektomija; } \\
\text { bilobektomija }\end{array}$ & $\begin{array}{c}\text { Explorativna } \\
\text { torakotomija }\end{array}$ \\
\hline $\begin{array}{l}\text { Kardiovaskul } \\
\text { arne }\end{array}$ & 7 & 2 & 0 \\
\hline Pulmološke & 4 & 1 & 1 \\
\hline $\begin{array}{l}\text { BP fistula } \\
\text { Pleuralni } \\
\text { empijem }\end{array}$ & 3 & 0 & 0 \\
\hline $\begin{array}{l}\text { Krvarenje iz } \\
\text { zida }\end{array}$ & 4 & 1 & 0 \\
\hline $\begin{array}{l}\text { Inflamacija } \\
\text { rane }\end{array}$ & 2 & 0 & 0 \\
\hline Nefrološke & 1 & 1 & 0 \\
\hline Smrt & 3 & 0 & 1 \\
\hline Ukupno & 27 & 6 & 2 \\
\hline
\end{tabular}

\section{DISKUSIJA}

Nakon postavljanja dijagnoze plućnog karcinoma, a zbog uznapredovalosti oboljenja samo $30 \%$ pacijenata je pogodno za inicijalni hirurški tretman.(5) Neoadjuvantna terapija predstavlja integralni dio multimodalog liječenja u inicijalnoj fazi, a u cilju postizanja sniženja stadijuma tumorske bolestu (down staging) i olakšanja provođenja hirurškog zahvata. Cilj primjene hemoterapije kod uznapredovalog i metastatskog NSCLC-a je produženje preživljavanja, poboljšanje kvaliteta života i ublažavanje tegoba.(6) U organiziaciji našeg zdravstvenog sistema dijagnoza bolesti u početnoj fazi je rijetka, te se ona postiže najčešće slučajnim radiogramima grudnog koša iz drugih razloga.

Detekcija pacijenata koje smo analizirali, odnosno poslije hemoterapije operativno tretirali, je u odmakloj životnoj dobi kod oba spola (AS 60,6 godina), a što bi upravo odgovaralo dugom evolutivnom toku bolesti. Učestalost oboljevanja u korist osoba muškog spola $(52: 15)$, bi pravdali češćim pušačkim navikama kod muškaraca i dokazanoj kancerogenosti duhanskog dima, te prilivu oboljelih iz područja sa rudarskom privredom (Zeničko-Dobojski Kanton) i dokazanoj zagađenosti zraka štetnim materijama $u$ navedenom regionu. $(7,8)$ Takođe veći broj oboljelih sa planocelularnim karcinomom (74,6\%), mogli bi pripisati navedenom razlogu (9)

Preporuke većine aktuelnih vodiča $u$ smjernicama neoadjuvantnog tretmana bolesnika sa uznapredovalom i metstatskom formom bolesti treba da bude na bazi platine, uz kombinaciju lijekova treće generacije. (10) U našem slučaju regresja bolesti u veličini za planocelularni karcinom je 26, $5 \mathrm{~mm}(17,0-38,0)$, adenokarcinom $38,0 \mathrm{~mm}(24,0.42,0)$ i makrocelularn karcinom $20,0 \mathrm{~mm}(18,0-22,0)$, a što odgvara dokazanom boljem odgovoru žljezdane forme karcinoma na hemoterapiju. (11)

Sve pacijente nakon reevaluacije smo operativno tretirali standardnim torakotomijskim pristupom, sa/ bez upotrebe vaskularnin staplera/katera, dok je bronh kod svih resekcionih zahvata reseciran staplerom, uz naknadnu prezervaciju bataljka rotiranim režnjem interkostalnog mišića ili pleure.(12) Najviše urađenih resekija je bilo tipa standardne ili 
proširene pulmektomije, dok je eksplorativnih torakotomija bilo 7,5\%. Najčešća rekvenca ranih postoperativnih komplikacija (Tabela 2), je kardiorespiratorne etiologije, uzimajući u obzir stariju dob oboljelih, te BP fistulu sa posljedičnim pleuralnim empijemom, vjerovatno zbog angiotoksičnog hemoterapijskog efekta.

\section{ZAKLJUČAK:}

U posmatranoj grupi pacijenata je pokazan značajan efekat primjene neoadjuvantnog hemoterapijskom protokola kao inicijalnog i preoperativnog vida liječenja oboljelih od nemikrocelularnog karcinoma pluća, a u cilju poboljšanja kvaliteta života i dužeg postresekcijskog preživljavanja.

\section{LITERATURA:}

1. Guska S. Procjena tehničke resektabilnosti plućnog karcinoma. Opšti principi savremene torakohiruške prakse. Medicinski fakultet Univerziteta u Sarajevu; 2012: 55-65.

2. Rivera C, Dahan M, Bernard A, Falcoz P, Thomas $P$. Surgical treatment of lung cancer in the ocogenarians. Cardio Thorac Surg. 2011: 981-988.

3. Massard G, Kochetkova E. Principes of treatment noncellular lung cancer. European respiratorian disease; 2006: 65-68.

4. Jaković R. Grudna hirurgija, Medicinski fakultet Univerziteta u Beogradu; 2004: 462
5. National Comprehensive Cancer Network. Non Small Cell Lung Cancer (Version 2.2014). http://www.nccn.org/professionals/physici an, pristupljeno mart 2017.

6. Vanstreenkiste J, Ruysscher D, Eberhardt W, Lim E, Senan S. et alt. Early and lokally advanced nonsmall-cell lung cancer: ESMO Clinical Practice Guidelines for diagnosis, treatment and follow-up. Ann Oncol 2012; 24 (6): 89-98.

7. Cigarette smoking among adults and trends in smoking cessation - United States, 2008. MMWR Morb Mortal Wkly Rep. Nov.2009; 58(44): 227232.

8. Lange P., Nyboe J., Jensen G., Schnohr P., Appleyard M. Relation of the type of tobacco and inhalation pattern to pulmonary and total mortality, Eur. Respir. J., 2002; 5(11): 112-117.

9. Morabia A., Wynder E. L. Dietary habits of smokers, people who never smoked and exsmokers, Am J CliaNutr, 2002; 52(7): 933-937.

10. van Meerbeeck JP, Kramer GW, Van Schil PE, et al. Randomized controlled trial of resection versus radiotherapy after induction chemotherapy in stage IIIA-N2 non-small-cell lung cancer. J Natl Cancer Inst 2007; 99: 442-450.

11. Graziano SL, Tatum A, Herndon JE 2nd, Box J, Memoli V, GreenMR, et al. Use of neuroendocrine markers, p53, and HER2 to predict response to chemotherapy in patients with stage III non-small cell lung cancer: a Cancer and Leukemia Group B study. Lung Cancer 2001; 33(2-3): 115-123.

12. Shields TW. Pathology of Carcinoma of the Lung. In: General Thoracic Surgery. Lippincott Williams and Wilkins. 2005; 6(2) :455-480

Summary: Introduction: In the most cases, bronchial cancer is a disease which is being discovered in a progressed phase when a radical surgical treatment, as a most important way of medical treatment, is limited. The aim of neo- adjuvant chemotherapy treatment is to bring the disease in a state when it is possible to carry out a surgical treatment. The aim of this dissertation: To demonstrate our experiences in a successful application of pre-operational oncological juvenile of treatment and efficiency of bringing a disease into "a lower level". Patients and methods: This analyses observed 67 patients of different ages and gender groups, which were, initially after the confirmation of a diagnoses, and because of localization and spread of the disease, impossible to carry out the surgical treatment. The above mentioned, after interdisciplinary approach were treated by neo- adjuvant chemotherapy protocol, and after it were radiographically bronchially reevaluated and undergone the surgical operation.

The results: There is no a statistically significant difference in the average valuations of the age of the patients in relation to their gender. $(p=0,052)$. Statistically there is a significant difference in frequency of appearance between two most common sorts of lung cancer at total number of patients. $\left(\chi^{2}\right.$ test $\left.=10,056 ; p=0,002\right)$. The difference in a size of regression according to a sort of tumor is not statistically significant. $p=0,091$. Conclusion: There is a significant effect of multimodal treatment of non micro celular lung cancer. 
Key words: lung cancer, inductive oncological therapy, surgical treatment.

Ademir Hadžismailović

Clinic for Thoracic Surgery, Clinical Center University of Sarajevo

Bolnička 25. 71000 Sarajevo, Bosnia and Herzegovina

Tel. 061159889,033298224

E-mail: ademirhadzismailovic@hotmail.com 